\title{
THE NEXT STEP IN GOVERNANCE: \\ THE NEED FOR GLOBAL MICRO-REGULATORY FRAMEWORKS IN THE CONTEXT OF EXPANDING INTERNATIONAL PRODUCTION
}

\section{BY}

\begin{abstract}
Karl P. Sauvant ${ }^{*}$
The final version is contained in T. C. Ambos, B. Ambos and J. Birkinshaw, eds., Perspectives on Headquarters - Subsidiary Relationships in the Contemporary MNC, in a section on "Additional Contributions by AIB Fellows," edited by Jean Boddewyn (Bingley, UK: Emerald, 2016), pp. 401-440.
\end{abstract}

\begin{abstract}
Explicit barriers to international trade, investment, technology, and financial flows have been reduced considerably. As a result, "macro-liberalization" of international economic transactions has largely run its course. Now, attention needs to shift from international rules for governments to international rules dealing with the various aspects of the international operations of firms - what are called "micro-issues" in this chapter; these include, by way of example, cross-border mergers and acquisitions and international bankruptcies. Such international rules for the principal actors in international production and markets would complement (or replace) the unilateral rules that exist at the national level. International rules would set the direct parameters for certain aspects of the international activities of firms and hence provide the global governance for operating in the global production and trading spaces. This chapter exemplifies for a number of areas the state of rule-making for some micro issues, analyses the nature of this rule-making and suggests a way forward. Developing international micro-regulatory frameworks of rules of the road for the various aspects of the international operations of firms in the globalizing world economy should be the new frontier of international commercial diplomacy.
\end{abstract}

Keywords: globalization, multinational enterprises, global governance, firm-level regulation. 
Explicit barriers to international trade, investment, technology, and financial flows have been reduced considerably. As a result, "macro-liberalization" of, and rule-making for, international economic transactions have largely run their course. Attention is shifting toward behind-the-border issues. ${ }^{1}$ But attention also needs to shift from international rules for governments to international rules dealing with the various aspects of the international operations of firms - what are called "micro-issues" in this chapter, including, by way of example, cross-border mergers and acquisitions (M\&As) and international bankruptcies. Such international rules agreed-upon by governments for the principal actors in international production and markets would complement (or replace) the unilateral rules that exist at the national level. Such international rules would set the direct parameters for certain aspects of the cross-border activities of firms and hence provide the global governance for operating in the global production and trading spaces. Developing international micro-regulatory frameworks of rules of the road for the various aspects of the international operations of firms in the globalizing world economy should be the new frontier of international commercial diplomacy.

Few such international micro-regulatory governance frameworks exist today below the macro-regulatory framework and for the global space the latter creates. Instead, firms are typically subject to a myriad of unilateral national rules. In the past, this was relatively unproblematic, as issues that concerned directly specific aspects of the operations of firms could be addressed effectively at the national level. Today, this situation makes it challenging for managers of multinational enterprises (MNEs) to navigate the regulatory frameworks of the countries in which their firms operate. It also creates governance gaps, that is, discontinuities between the needs of global markets and an integrated international production system and the global value chains that are part of it, on the one hand, and the reach of (different) national regulatory frameworks dealing with internationally operating firms, on the other. Thus, for instance, when firms headquartered in one country engage in cross-border M\&As, go bankrupt, engage in lending, establish closed user-group networks (such as airline reservation systems), report on their financial performance, offer insurance services, rate the credit worthiness of other firms or governments, produce inferior goods that endanger consumers, or engage in transactions with entities in sanctioned countries, firms and consumers from many countries, as well as various governments, may well be affected. ${ }^{2}$ In 2014, the recognition of such a governance gap in one particular area led the G-20 to deal as a group with tax avoidance by MNEs. ${ }^{3}$

While this chapter suggests that international micro-regulation is necessary, and that governments and other players have to attend to this need, more regulation - and that of a multilateral kind - is understandably controversial. The discussion below recognizes that sentiment, as shown in the section that sets out the advantages of the current ad hoc approach. The objective is to raise an issue -- more through examples than anything else -rather than to offer full-fledged solutions or conclusions. Indeed, one of the points that require attention is precisely the trade-offs relating to the advantages and disadvantages of a government-led systematic approach leading to mandatory international instruments, on the one hand, and a market-driven ad hoc approach leading to voluntary international arrangements, on the other. ${ }^{4}$ In either case, though, the challenge is to adapt to the realities of a globalizing world economy and the integrated international production system that is at its core. ${ }^{5}$

\section{MACRO-LIBERALIZATION HAS LARGELY RUN ITS COURSE}

Consider the following developments:

- Bound tariffs of developed countries on trade in industrial products were reduced by about 75 percent between 1967 and $2000,{ }^{6}$ and they were further reduced in 
subsequent years on particular products. Disciplines are being put in place to dismantle non-tariff barriers. Trade in services is being progressively liberalized, though mostly on a non-committed, that is, reversible, basis. The world trading system has been strengthened with the establishment of the World Trade Organization (WTO) and its dispute-settlement mechanism.

- Financial liberalization has proceeded even faster than the liberalization of trade, perhaps too fast for some countries. A global financial architecture is emerging (even if it needs adaptation), overseen by the IMF.

- Many obstacles to the flow of foreign direct investment (FDI) have been removed, with the great majority of policy changes at the national level going in the direction of making the investment climate more welcoming for foreign investors (although increasingly so in a more nuanced manner). At the same time, standards for the protection and treatment of international investors have been strengthened through over 3,000 international investment agreements. ${ }^{7}$ In addition, some two-thirds of world FDI flows are covered by the WTO's General Agreement on Trade in Services, with the bulk of the rest covered by regional or bilateral agreements (which, although typically called "free trade" agreements, are increasingly becoming "free investment" agreements as well).

- The defensive national transfer-of-technology regimes of the 1960s and 1970s have given way to a strong multilateral system for the protection of intellectual property rights, embodied in the WTO's Agreement on Trade-Related Intellectual Property Rights (TRIPS) (UNCTAD-ICTSD, 2005). This regime is further expanded by regional and bilateral agreements. The international technology market has never been more favorable for the owners of intellectual property.

To be sure, things are far from perfect, setbacks take place and a number of issues remain outstanding. For example, protectionism remains an ever-present danger, both in the trade and international investment areas. ${ }^{8}$ The Eurozone is under strain. Some key sectors of particular interest to developing countries (notably agriculture and textiles) are still not significantly liberalized. The movement of labor has barely received attention, and a multilateral framework for investment is still lacking. But, otherwise, the outstanding trade issues are either clear cut (e.g., to reduce tariff peaks and tariff escalation), or they are shifting more and more toward fairly technical questions of implementation (e.g., special and differential treatment for developing countries) or to trade-related issues (e.g., environment, competition). Similarly, managing the formidable global financial market, reducing its instability and strengthening the global financial architecture remain a challenge. Tackling these outstanding issues is difficult. They are part of the (unfinished) old agenda, and they need continued attention.

Overall, however, the basic rules are largely in place. They constitute an open global macro-regulatory framework for international trade in goods and services, financial transactions, investment, and the movement of technology between and among countries, with the WTO and the IMF at its heart. This framework is far from perfect, and it has one glaring omission: it does not address restrictions to labor mobility to any significant degree. ${ }^{9}$ It is also difficult to manage. It is challenged by bilateral and regional deals. Its coherence is imperfect. But it is in place and, on the whole, it is fairly robust.

\section{GLOBAL SPACES, GLOBAL ACTORS}

The most important characteristic of the global framework mentioned above is that it opens global spaces for firms to pursue their activities internationally. Information, communication and transportation technologies have made it possible for firms to operate globally in real time. Competition among firms makes it likely that, what is possible, is 
being exploited by firms, in pursuit of their own international competitiveness and profitability.

The extent to which this has already happened is reflected in the fact that, between 1990 and 2014, world exports of goods and services rose from US\$ 4 trillion to US\$ 23 trillion; world royalties and licensee fee receipts grew from US\$29 billion to US\$ 310 billion; and world FDI outflows increased from US\$ 241 billion to US\$ 1,200 billion (UNCTAD, 2015, p. 18). The volume of cross-border capital flows grew to nearly US\$ 12 trillion in 2007, before collapsing (due to the financial crisis that began in 2008) to close to US\$ 5 trillion in 2012 - still, an enormous amount of funds, testifying to the openness of the international financial system (Lund et al., 2013, p. 4).

Among firms, MNEs are particularly important actors. The number of MNEs headquartered in 15 OECD countries rose from 7,300 at the end of the 1960s (with some 27,000 foreign affiliates) (United Nations, 1973, pp. 135, 147) to, world-wide, 65,000 around the turn of the century (with around 850,000 foreign affiliates) (UNCTAD, 2002, p. 270) to, again worldwide, at least 100,000 at the end of 2010 , controlling a minimum number of 900,000 foreign affiliates (UNCTAD, 2012, web table 34). (The actual number of MNEs and their foreign affiliates is likely to be considerably higher, as their coverage across countries is very uneven.) Moreover, the universe of international investors is diversifying, as private equity firms, hedge funds, more state-owned enterprises, sovereign wealth funds, and born-global entrepreneurial firms engage in international production. Moreover, firms from developing countries and economies in transition are also increasingly becoming multinational, ${ }^{10}$ with FDI outflows in 2014 from these countries (US $\$ 530$ billion) being roughly eleven times higher than world FDI flows during the first half of the 1980s. Especially in developed countries, the expansion of MNEs takes place mainly through M\&As, ${ }^{11}$ fuelling a global market for firms.

Given the largely open macro-framework, MNEs consider the world as one production space. Accordingly, they organize their production internationally by locating their affiliates wherever in the world particular parts of the value chain (be it in goods or services) can be produced best from their point of view, creating an international intra-firm division of labor. ${ }^{12}$ Moreover, firms that are not tied to particular parent firms through ownership arrangements are increasingly becoming part of these production networks through non-equity arrangements. International intra-firm trade, technology and knowledge flows tie the various units of individual corporate networks together, which remain under the common governance of their headquarters. ${ }^{13}$ While parent firms remain the ultimate decision-makers, the role of headquarters increasingly becomes that of deciding where various production activities take place, organizing highly complex networks, providing key tangible and intangible assets (e.g., finance, brand names, research and development), and orchestrating information and knowledge flows within the networks. ${ }^{14}$ The results are corporate integrated international production systems (UNCTAD, 1993) and the global value chains that define them (UNCTAD, 2013). ${ }^{15}$ In aggregation, these add up to the expanding integrated international production system that is the productive core of the globalizing world economy.

This process is reflected in the fact that roughly one-third of world trade consists of intra-firm trade, and an even higher percentage is associated with global value chains (UNCTAD, 2013), internalizing in this manner certain types of international transactions. International production - production by foreign affiliates (US\$36 trillion, compared with world exports of US\$23 trillion, both in 2014; UNCTAD, 2015, p. 18) - has become more important than exports in delivering goods and services to foreign markets. The combined domestic and foreign output of MNEs suggest that as much as one-quarter of world output 
- if not more -- is under the common governance of MNEs, with a percentage that is considerably higher in a number of industries (UNCTAD, 1999).

In sum, technological innovations in communications and transportation have combined with government policies to shrink the distances that once separated the economies of this world. Competition among firms has ensured that the new opportunities are being utilized, as reflected in the expansion of international economic transactions undertaken by them. The production and market spaces in which many firms operate are no longer national. Rather, an integrated international production system, centred on developed countries but becoming wider, is emerging, complementing the global markets for goods, services, intellectual property, and capital, and driven by global actors.

\section{THE NEED FOR INTERNATIONAL MICRO-REGULATORY FRAMEWORKS}

With an open macro-framework largely in place, the spotlight falls on firms, the principal actors in the international production process and in international markets. They - whether large or small, from developed or developing countries - drive the globalization process through trade, finance, technology transfer, and foreign direct investment.

To deal with firms at the international level, however, requires a paradigm shift in international commercial policy making: rules should no longer only govern the action of governments at the national level but also the operations of firms at the international level. ${ }^{16}$ With more and more firms operating globally and in an integrated manner, more and more corporate issues acquire an international dimension as well. Even firms in big countries, be they developed or developing, are virtually compelled to orient their activities beyond their domestic markets. ${ }^{17}$ They have become (or are becoming) part of the world economy - via exports and imports, inward and outward investment, alliances, licensing and franchising arrangements, and other business transactions. Rules need to adapt to the reality of the globalizing and integrating world economy: national regulation alone of the operations of firms is no longer sufficient, in fact, effective, in a globalizing world economy. Stable, predictable and transparent global governance rules dealing with the operations of firms are needed.

To put it differently, the logic of the globalization process and, in particular, the emergence of an integrated international production system and the global value chains that are part and parcel of it, require that the national rules governing corporate operations most affected by the globalization and integration process be complemented, if not supplanted, by global micro-regulatory frameworks. It is a process that involves the internationalization of some aspects of the domestic policy agenda relating to firms (Ostry, 1992). Only when an open macro-framework is complemented by appropriate microframeworks governing the various types of operations of firms - animal spirits aside - can firms prosper, and public and private interests be properly balanced. ${ }^{18}$ The creation of such frameworks requires deliberate attention and action.

The nature of such frameworks for the various types of operations of firms, the contents of its rules, and how the frameworks and rules are formulated and enforced (and hence which interests they reflect), are of critical importance for all firms, as they influence who benefits from the way in which corporate activities are carried out. This is true for firms from both developing and developed countries: in a world in which production systems and markets are global and profit preserves are disappearing under the onslaught of liberalized trade, technology, investment, and financial flows, competition is everywhere. There is a particular need to see to it that firms in developing countries are not disadvantaged in this competition, as competitive firms are the bedrock of growth and development. Micro-rules set the parameters for the international competitiveness of firms and hence influence the extent to which the development prospects of the countries in 
which they are located can be advanced. It is a challenge to make sure that firms based in developing countries are not disadvantaged, as most of the governments of these countries, as well as the business associations in these countries, typically have only limited capacity to deal with such matters.

The establishment of micro-rules for the operations of firms in the globalizing and integrating world economy should be the new frontier for international commercial diplomacy. It is in fact the rise of an integrated international production system and the global value chains that are part and parcel of it that render this challenge more urgent than before. The question therefore arises: how are these rules to be created and by whom? Indeed, governments have begun to recognize the importance of, and need for, micro-rules in the context of bilateral and regional trade agreements. ${ }^{19}$ However, in the absence of a multilateral dialogue on these issues, this risks creating mutually inconsistent regulatory regimes, partly overlapping, which, in turn, would impose high administrative burdens on MNEs and could distort their locational decisions and it would not necessarily reflect an appropriate balance between public and private interests.

\section{CURRENT MICRO-REGULATORY FRAMEWORKS}

So far, little systematic attention has been given to the issues that global micro-regulatory frameworks need to address, the substantive content of such frameworks and the modalities of creating them. ${ }^{20}$ Rather, to the extent that global micro-rules have emerged, they have typically done so reactively (e.g., in reaction to specific problems as they arise), and they have often been created by a limited number of business actors, typically from developed countries. This haphazard, market-driven process is in danger of not taking the interests of other actors - especially firms from developing countries and various stakeholders - fully into account.

What is the nature of current micro-regulatory frameworks? Consider the following examples:

- Mergers and acquisitions. If two large MNEs merge, the competition authorities in the countries in which the two have affiliates (not to count the countries that may be affected by such transactions via trade) may need to authorize the transaction for it to go ahead since, frequently, antitrust issues have to be considered. ${ }^{21}$ (Table 1 gives an indication of the minimum number of countries that would be affected if one of the large financial MNEs should be acquired by, or merged with, another large financial firm.) Each country has its own review processes, procedures, criteria, priorities, and time-frames for M\&As. This can cause delays, uncertainty, costs and, in some cases, the abandonment of a merger plan. ${ }^{22}$ Moreover, smaller countries (and especially developing countries) typically do not have the resources and expertise to examine the effects that large-scale M\&As of this sort may have on them. 
Table 1. The international presence of large financial MNEs, majority-owned foreign affiliates, 2012

\begin{tabular}{lll}
\hline Name & Home economy & Number of countries in which MNE is established \\
\hline & & 74 \\
Citigroup Inc & United States & 69 \\
BNP Paribas & France & 65 \\
Allianz SE & Germany & 65 \\
HSBC Holdings PLC & United Kingdom & 61 \\
Societe Generale & France & 56 \\
Deutsche Bank AG & Germany & 54 \\
Munich Reinsurance Company & Germany & 53 \\
Assicurazioni Generali SpA & Italy & 50 \\
UBS AG & Switzerland & 48 \\
Berkshire Hathaway Inc & United States & 46 \\
Barclays PLC & United Kingdom & 45 \\
Standard Chartered PLC & United Kingdom &
\end{tabular}

Source: UNCTAD, 2013.

If anything, this issue is becoming more urgent, as reflected in the growth of international M\&As: the value of cross-border M\&As rose from US\$ 100 billion in 1990 to a peak of US\$ 1 trillion in 2000, fluctuating thereafter between US\$ 167 billion and US\$ 1 trillion until $2014 .{ }^{23}$ The number of such deals rose from 862 in 1987 to 7,800 in 2000 (UNCTAD 2000, p. 232, UNCTAD 2002, pp. 11), to reach 8,624 in $2013 .^{24}$

An international market for firms needs international rules for cross-border M\&As. In the absence of such rules, enforcement remains a domestic responsibility and inter-governmental cooperation is ad hoc, pretty much restricted to the U.S. and European Union competition authorities. ${ }^{25}$ This is even more a challenge as the number of competition authorities has risen considerably in recent years (see Figure 1). While this is a positive development, it multiplies complexities and creates uncertainties for firms.

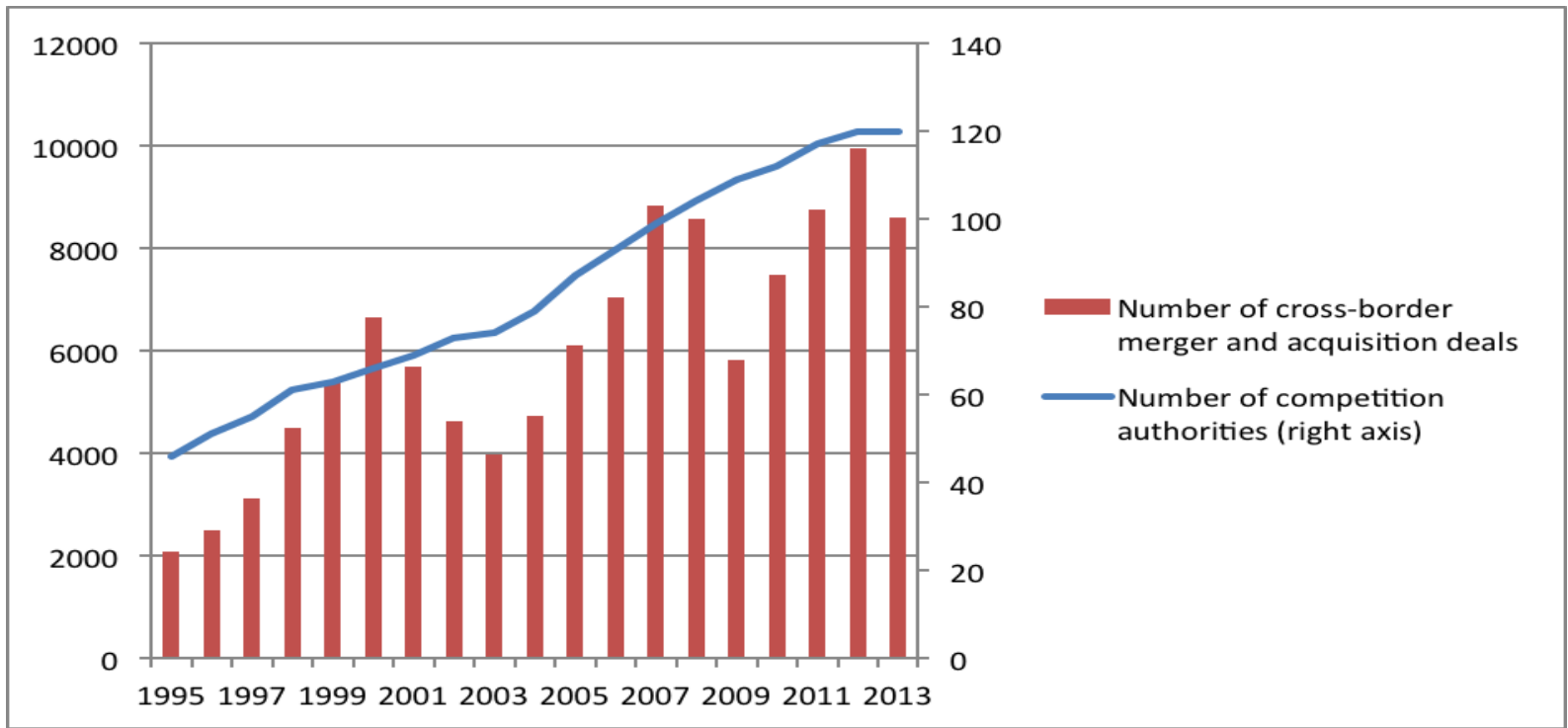

Figure 1. More competition authorities dealing with more cross-border mergers and acquisitions, 1995-2013 
Source: OECD, Challenges of International Co-operation in Competition Law Enforcement (Paris: OECD, 2014), available at www.oecd.org/daf/competition/challengesinternational-coop-competition-2014.htm, pp. 24, 27.

- Bankruptcy. If a large MNE goes bankrupt today, not only its home country but also the many host countries in which it has affiliates are directly affected (Table 1). A high-profile early example was the 1991 collapse of the Bank of Credit and Commerce International (BCCI), which at that time operated 380 offices in nearly 70 countries the largest international banking failure at that time. Another example was the demise of Polly Peck International, a smaller United Kingdom-based conglomerate; differences between legal systems and insolvency laws held up the settlement of this case for several years. ${ }^{26}$ More recently, the collapse of Lehman Brothers led to a bankruptcy that spanned nine jurisdictions. This time, however, interested parties organized the proceedings under a private protocol, allowing jurisdictions to intervene in each other's proceedings.

However, most global bankruptcies still operate on a territorial basis, with separate filings in each different country (Altman, 2011, pp. 469-470). In the absence of an international approach to bankruptcies, each country seeks to "ringfence" the assets located on its territory, with little regard to the possible rescue of the enterprise as a whole: this is a problem because, to the extent that individual foreign affiliates are fully integrated into their corporate networks, they are typically not viable on their own, so that, in the end, both the host and home countries involved are negatively affected. With more than 100,000 MNEs (a number that is increasing), more and more of them having a rising number of affiliates in a growing number of countries, and more and more being fully integrated into the international production networks of their parent firms, more and more complicated bankruptcy cases are likely to occur. No international rules for corporate bankruptcies exist, although the United Nations Commission on International Trade Law (UNCITRAL) has developed a Model Law on Crossborder Insolvency. ${ }^{27}$

- Minimum capital reserve requirements for banks, as part of the regulation of financial institutions. The financial sector is one of the most important sectors in any economy, and it is generally very internationalized. Minimum capital reserve requirements for banks are key to the stability of this sector; national banking supervision authorities set those requirements. Work on harmonized standards for banking supervision has been on the agenda of the Basel Committee on Banking Supervision for some time. More specifically, the Committee's mandate is "to strengthen the regulation, supervision and practices of banks worldwide with the purpose of enhancing financial stability." 28 The Committee's decisions do not have legal force, but, de facto, represent governance in this particular area of activity. Rather, the Committee "expects full implementation of its standards" by its members (representing 27 jurisdictions ${ }^{29}$ ) "and their internationally active banks." ${ }^{30}$ In practice, many non-members adopt the Committee's rules as well, owing to the lack of widely accepted alternatives and the standing of the Committee's rules in international financial markets for institutions that depend on such markets. For example, by July 2014, all Committee members had implemented, or were in the process of implementing, Basel III (a comprehensive set of reform measures developed by the Basel Committee), in addition to 89 non-Basel Committee member jurisdictions. ${ }^{31}$ 
- Airline computer reservation systems (CRSs). Airline CRSs gather all flight-related information on single platforms. Being listed on such a platform, and the precise place where the listing appears (especially on the first screen), can be crucial for airlines to attract customers. Travel agents use CRSs regularly to find flights corresponding to their clients' demands, and individuals increasingly do the same. During the mid1970s, a few major airlines first developed CRSs that were used by the majority of airlines and travel agents. The CRS-developing airlines were soon accused of using CRSs to privilege their own flights. In the 1980s, national and regional authorities started regulating the use of CRSs, for antitrust purposes. In 1984 and 1992, for example, the U.S. Department of Transportation adopted CRS regulations prohibiting display bias and forcing airlines that used one CRS to list their flights on other CRSs as well (Caliskan and Cochran, 2003, pp. 1-3). ${ }^{32}$ The European Community took similar steps in $1989^{33}$ (Milde, 2008, p. 115). On the whole, CRSs and air traffic worldwide came to be regulated by a web of bilateral treaties in the absence of multilateral solutions ${ }^{34}$ (Abeyratne, 2005-2006, p. 39). To complicate matters further, United States and European Union competition laws often provided for their application beyond their own borders (as shown by the U.S. regulation of CRSs), leading to conflicts of laws (Abeyratne, 2005-2006, p. 61). In 1986, the International Civil Aviation Organization (ICAO) established itself as the main body within the United Nations to regulate international air transport (Abeyratne, 2005-2006, p. 47). The ICAO issues model codes and non-binding guidelines ${ }^{35}$ to harmonize airline competition laws throughout the world (Abeyratne, 2005-2006, p. 43).

- Accounting and reporting standards. At present, MNEs in developed countries keep at least two sets of accounts: consolidated (group) accounts ${ }^{36}$ according to the reporting requirements of their home countries, and accounts of individual foreign affiliates according to national accounting standards of the countries in which each affiliate is registered. Group accounts in most cases are prepared in accordance with one of two major accounting systems: the International Financial Reporting Standards developed by the International Accounting Standards Board, ${ }^{37}$ or the U.S. Generally Accepted Accounting Principles, established by the U.S. Financial Accounting Standards Board. ${ }^{38}$ Firms from developing countries and from economies in transition in most cases have to use one of the two systems or variations of them for the purpose of helping them obtain access to international capital markets. Many economies in transition and a number of developing countries are in the process of reforming their national accounting systems by either adopting the International Financial Reporting Standards in full, or developing new national regulations on the basis of this standard. As of April 8, 2015, 114 jurisdictions required the application of International Financial Reporting Standards for most or all domestically listed companies, while 128 (out of 138) jurisdictions had publicly committed to the convergence of accounting standards. ${ }^{39}$ When weaknesses in the U.S. Generally Accepted Accounting Principles were revealed by the collapse of Enron and by subsequent corporate scandals, the U.S. Congress approved the Sarbanes-Oxley Act in July 2002 to improve corporate governance (Box). This legislation applies to all companies listed on United States stock exchanges, regardless of whether they are headquartered in the United States or not; ${ }^{40}$ it also applies to foreign affiliates of U.S. MNEs.

Today, the International Financial Reporting Standards are the world's most widely adopted standards. The International Accounting Standards Board and the U.S. Financial Accounting Standards Board have engaged in efforts to bring about a convergence of the two accounting standards, and both are now quite similar. The 
U.S. Financial Accounting Standards Board, however, has not agreed to adopt the International Financial Reporting Standards as the U.S. standard. ${ }^{41}$

Box. The Sarbanes-Oxley Act: a study in global standard setting by one country.

The Sarbanes-Oxley Act is a case study of a reactive approach to rule-making. It is also a case study of how, under the pressure of time to respond to an acute crisis, rule-making may not always be undertaken carefully; what technical micro-rules are like; and how in the absence of an international approach, action by one government can have implications for other governments and their regulatory regimes.

When Enron went bankrupt on December 2, 2001, Senator Paul Sarbanes and Congressperson Michael Oxley introduced, on January 23, 2002, corporate reform legislation that gained momentum as additional scandals broke. It was approved by both Houses of the U.S. Congress in July 2002, and signed into law by President George W. Bush on July 30, 2002. According to the $C P A$ Letter, ${ }^{a /}$ it is "the most significant legislation affecting the accounting profession since 1933." The Financial Times added: $:-$ "most of those affected now admit that it was hastily drawn up."

While the Act deals with corporate reform in the United States, its implications reach beyond that country as it applies to all companies listed on U.S. stock exchanges as well as to the foreign affiliates of U.S. firms. At the same time, a number of its provisions were in conflict with approaches taken outside the United States. For example, the Act required that all members of a company's audit committee be independent; this conflicted with the German law that all firms with more than 2,000 employees fill half of their supervisory board seats with elected work-force representatives, with some of them also being members of the audit committee. Another example was the requirement that the chief executive and financial officers needed to certify their firms' financial statements and, hence, become personally responsible for misstatements; in Germany, on the other hand, these matters were the collective responsibilities of the management board. The Act (Sec. 106) also allowed U.S. authorities to raid the offices of European accounting firms in case of controversy between such firms and the U.S. Public Oversight Board. In fact, virtually all non-U.S. firms are subject to the Board's inspections. While most jurisdictions do not object, a few jurisdictions (like China and Hong Kong (China)) are reluctant to grant access to the Board. In many cases, the Board conducts investigations in

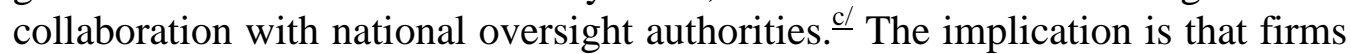
can either de-list themselves from U.S. stock markets, thereby losing direct access to the world's most important capital market, or they can seek exemptions from certain provisions (which, for example, the European Commission was doing); the granting of exemptions might reflect, of course, the importance of the requestors and the strength of their own corporate governance standards. Companies could, of course, comply by changing their own practices if their national laws permit it.

In sum (to quote the CPA Letter again ${ }^{\mathrm{d} /}$ ): "High-profile business failures . . . called into question the effectiveness of the profession's self-regulatory process 
..." The resulting legislative remedy, in the words of a commercial law expert in Tokyo, amounted to: "Global standards are beginning to mean US standards imposed elsewhere."

al Vol. 82, September 2002, p. 1.

b/ December 30, 2002, p. 9. The newspaper quoted Oxley as saying that the bill was "passed in almost a panic sort of situation" (ibid.).

"Non-US firms inspections," PCAOB's website, available at http://pcaobus.org/International/Inspections/Pages/default.aspx, last visited April 8, 2014.

d/ Vol. 82, September 2002, p. 1 .

el Financial Times, December 30, 2002, p. 9.

- Insurance regulation. Insurance, too, is a sector of critical importance to any economy. The International Association of Insurance Supervisors was established in 1994, with a permanent secretariat in Basel. ${ }^{42}$ Representing insurance regulators and supervisors in nearly 140 countries, the Association agrees on "core principles" for the supervision of insurance operations, and all its members adopt these. The IMF uses its guidelines and standards when vetting the reinsurance frameworks of developing countries. The Association's "Emerging Markets Committee" deals with issues of special concern to developing countries.

- Credit rating. Standard \& Poor's, Moody's and Fitch (all three headquartered in New York) dominate the market for the credit rating of companies and governments. When any of them reduces the credit-worthiness of a government or a company, there can be immediate implications for its access to capital markets and especially the costs at which it can borrow money. In a sense, this makes these three firms quasi-official regulators of public and private debt markets.

- Business-to-consumer commerce. Cross-border commerce has long been largely limited to business-to-business transactions, regulated by international uniform substantive law such as the International Convention on the Sales of Goods. ${ }^{43}$ Recently, however, the use of the Internet has led to unprecedented cross-border transactions directly between businesses and consumers. These transactions, however, are yet to be regulated by uniform international rules. As of 2014 , online dispute resolution generally was the only way to resolve cross-border business-to-consumer disputes (Johnson, 2013, p. 582). Various attempts to apply national laws have failed. ${ }^{44}$ Treaty negotiations between the United States and European Union authorities have also proved unfruitful so far. ${ }^{45}$ This results in considerable legal uncertainty likely to deter both consumers and businesses from engaging in crossborder transactions. It also reduces consumers' influence on the legal landscape of consumer protection. Consumer groups advocate legislative change in their respective countries, only to see national law supplanted by ad hoc cross-border dispute resolution processes that rely on fair principles of international law (Stewart and Matthews, 2002, p. 1136).

- Corporate transactions with countries on which sanctions have been imposed. As the 2014 example of BNP Paribas's $\$ 8.9$ billion settlement ${ }^{46}$ illustrates, corporate entities often must comply with foreign sanctions laws; in this case, BNP pleaded guilty to having processed billions of dollars of transactions through the U.S. financial system on behalf of Cuban, Iranian and Sudanese entities subject to U.S. economic sanctions (Zagaris, 2014). Some U.S. sanctions laws, for example, apply to foreign-owned subsidiaries of U.S. parent companies, foreign companies re-exporting U.S. goods to 
sanctioned entities and foreign companies conducting transactions through the United States' financial system (Rathbone et al., 2013, pp. 1107-1119). This extraterritorial application of U.S. law has resulted in conflicts of laws. For instance, foreign companies were threatened with U.S. sanctions for selling Cuban products or providing services to Cuban officials; on the other hand, national laws prohibited them from discriminating against Cuban products or officials. ${ }^{47}$ More generally, foreign sanctions laws expose MNEs to compliance obligations arising from foreign jurisdictions that can conflict with the laws of their home jurisdictions. In many cases, conflicts of laws have been avoided thanks to international consensus on sanctions: for example, after the U.S. Congress passed a new sanctions law prohibiting foreign financial and oil companies from certain transactions with Iran, the European Union enacted similar provisions so as to manifest its agreement with the sanctions and eliminate conflict-of-law issues (Rathbone et al., 2013, pp. 1122-1123). However, unilateral sanctions with extraterritorial application remain to be harmonized in a systematic way, which would arguably prompt issues of political governance. ${ }^{48}$

As these examples illustrate, the regulation of global corporate operations -- its governance -- can take various forms and have different strength (mandatory, voluntary). It also has many sources (ranging from strictly national to international approaches), originates from the private sector or individual governments, and it can be entirely absent. For example:

- Absence of global rules. Such is the case, for example, in matters of bankruptcy, business-to-consumer transactions and transactions with politically sanctioned entities. In bankruptcy matters, the case of Lehman Brothers shows that national legal systems are still entirely independent in this particular area. When an MNE faces bankruptcy in multiple jurisdictions, it has no international rules to fall back on in order to restructure itself and become viable again. In the absence of global rules, voluntary and ad hoc cooperation among jurisdictions has been the only approach to deal with such situations.

- Corporate actions with a global governance impact. Some corporate pronouncements have such an impact throughout the world that they amount to sector-specific "governance". In the credit-rating area, for example, private companies based in the United States (such as Moody's, Standards \& Poor's, Fitch) can impact companies and governments' borrowing abilities, whether in the United States or elsewhere. They have assumed a sort of de facto international quasi-regulatory role (but are themselves not regulated by anyone). They are actors that have emerged to fill a need.

- Mandatory national regulations that, de facto, become international regulations. For example, the United States' Sarbanes-Oxley Act is a national regulation with an international impact: it became, de facto, an international regulation as it applied to all companies - even foreign ones - registered with the U.S. Securities and Exchange Commission, as well as to the foreign affiliates of U.S. MNEs. Similarly, the regulation of airline computer reservation systems by the U.S. Department of Transportation not only protected every airline to a certain extent (regardless of nationality) from display bias, but also prohibited ${ }^{49}$ them from using such bias in their own computer reservation systems. Finally, U.S. sanctions laws apply not only to U.S. companies, but also to foreign-owned subsidiaries of U.S. companies and foreign companies that use the United States' financial system or re-export U.S. goods.

- Model arrangements that can serve as templates for the cooperation of countries in specific areas. The above-mentioned UNCITRAL bankruptcy Model Law is an example. The Model Law does not aim at unifying different national laws, but provides cooperation provisions for incorporation in existing 
laws. National laws based on the Model Law empower courts of different countries to communicate and cooperate in making decisions. For instance, national laws based on the Model Law would facilitate the recognition of orders issued by foreign courts. It also gives foreign creditors and court officials a right of access to the courts of an enacting state. By early-2015, 21 countries had adopted legislation based on UNCITRAL's Model Law. ${ }^{50}$ In particular, the U.S. Congress updated the country's Bankruptcy code in 2005 with a new chapter (Chapter 15) providing a window for cooperation with foreign courts and foreign parties. ${ }^{51}$ Chapter 15 is now used in bankruptcies of multinational entities. In 2009, for example, the Southern District of New York agreed to recognize foreign bankruptcy proceedings regarding a Switzerlandincorporated subsidiary of Lehman Brothers (U.S. G.A.O., 2011).

- International private regulation. In matters of accounting and insurance, the International Accounting Standards Board and the International Association of Insurance Supervisors harmonize corporate practices on a global basis. Neither of the two are governmental bodies. Rather, they are both not-for-profit organizations, with ties to national supervisory and regulatory entities. The International Accounting and Standards Board is accountable to the International Financial Reporting Standards Foundation, which is accountable (through its Board of Trustees) to the Monitoring Board, a "body of publically accountable market authorities" (among which are the SEC and the European Commission). ${ }^{52}$ The International Association of Insurance Supervisors relies on voluntary membership of supervisors and regulators (public and private) from nearly 140 countries. It counts the European Commission and the U.S. Federal Insurance Office among its members. ${ }^{53}$

- International government regulation._In some areas, the international regulation of certain activities involves virtually all countries. An example is the International Labour Organization under which agreements are forged whose main aims are "to promote rights at work, encourage decent employment opportunities, enhance social protection and strengthen dialogue on work-related issues." 54 But there are also certain activities for which a limited number of public authorities make de facto rules accepted by many (if not most) countries. In the financial area, the Basel Committee brings together 27 jurisdictions, but its decisions are accepted by more than 100 jurisdictions. However, decisions are largely made by the G-10 developed countries, although the Committee expanded in 2009 to include such emerging markets as Brazil, China, India, and Russia. Still, developing countries in general seem to have little influence on the Committee's rulemaking. ${ }^{55}$ While the Committee's regulations are voluntary (i.e., have no legal force), they reach virtually all internationally active banks.

Overall, what characterizes most of the micro-regulatory efforts undertaken so far is that:

- They are partial in the sense that they address only some areas relevant to the range of corporate operations. Presumably, these are areas that, at a certain point, were particularly pressing in a globalizing environment and/or had drivers behind them that were strong enough to promote international approaches.

- They are sometimes geographically quite restricted. In fact, it may be only one country, or a small group of countries, that makes rules that become de facto global standards.

- They are elaborated by a variety of entities, sometimes in combination with each other: sometimes by governments (or specific governmental institutions), sometimes by the legislative authorities of a few or even of a single country, sometimes by the 
business community, sometimes by professional associations, and sometimes by one or a few dominant companies. ${ }^{56}$

- Governments, business associations or firms from developing countries are often not involved in the rule-making although the rules may apply de facto equally to all firms wishing to participate in the integrated international production system or the global trading system. Even when the bodies involved pay attention to developing countries, development issues are not vital to them.

There is also the question of global rules concerning the responsibilities of market actors, and especially MNEs. An early effort to formulate a set of such rules was made in the late 1970s and 1980s, when the United Nations sought to negotiate a comprehensive set of rules dealing, among other things, with the responsibilities of MNEs, an effort that came to naught (Sauvant, 2015). However, such rules, albeit voluntary ones, were adopted by the Organisation for Economic Co-operation and Development (OECD), ${ }^{57}$ and they exist in a number of sectors ${ }^{58}$ (most recently related to human rights ${ }^{59}$ ). This issue remains on the international agenda, including in the context of improving the international investment law and policy regime, and, sooner or later, is likely to be addressed.

As this discussion indicates, there are many efforts to build international microregulatory frameworks, involving a wide range of private and public institutions. It is a patchwork of efforts, with uneven geographical coverage and a variety of drivers, and it does not cover important operations of firms in a satisfactory manner. In a by-and-large reactive market-driven process, global production and market rules tend to evolve ad hoc to satisfy primarily the operational requirements of firms from developed countries, and they are voluntary. They are often informed by and/or agreed upon in "webs of influence" (Braithwaite and Drahos, 2000) by a relatively small group of large firms from developed countries (or semi-private professional associations, typically dominated by representatives from developed countries). At times, they have acquired official status, especially through action by the competent regulatory agencies of developed countries. Governments too may take the initiative and introduce mandatory rules. Rules are often updated in light of the experiences of the principal firms affected by them and of the changing conditions in (primarily) developed countries. Most countries, and especially developing countries, tend to be rule-takers, not rule-makers. The conditions and interests of firms from these countries are therefore not a prime concern influencing the setting, implementation and revision of the rules. As a result, firms from countries for which these rules may not be adequate may be at a disadvantage. They may even constitute barriers to their participation in the integrated international production system and global markets. Yet, the emerging micro-regulatory frameworks increasingly determine the competitive position of firms across the world and, by extension, the benefits countries derive from them. ${ }^{60}$

\section{THE NEW AGENDA}

Is this reactive process of global rule-making satisfactory and sustainable, or even desirable? In particular, is it satisfactory and sustainable in a globalizing world economy:

- That crises are needed, or that a situation becomes obviously unacceptable,${ }^{61}$ to set a rule-making process in motion?

- That issues that need an international approach continue to be left to a few (often competing) national jurisdictions, with a potential for inefficiencies and even conflict?

- That the global operations of firms might be disrupted because of some rules' limited geographical application? Or, alternatively, that certain geographical areas are left out from the rule-making or are rule-takers with little influence on the emerging global micro-regulatory frameworks? 
- That one group of governments (or individual parts of one or several governments) can make rules for the rest of the world?

- That global rules are defined, at least de facto, by parts of the business community or individual firms, reflecting private (but not necessarily public) interests (including the possibility of hidden protectionism)?

- That, in each case, perhaps only the (limited) interest of the rule-makers determine the content of the rules?

These questions are particularly relevant considering that the multinationalization of firms is most likely to continue unabated and, with it, the expansion of the integrated international production system. This is not only reflected in the figures mentioned earlier regarding the growth of the number of firms that have become MNEs and the rise of FDI flows. It is also reflected in the extent to which firms that are already MNEs have become more multinational: thus, the degree of multinationalization of the world's 100 largest nonfinancial MNEs, ${ }^{62}$ as measured by a composite transnationality index that captures the proportion of foreign assets, employment and sales in their respective totals, grew from 47 in 1993 (UNCTAD, 2007, p. 15) to 56 in 2003 (UNCTAD, 2007, p. 15) and to 67 in 2013 (UNCTAD, 2014, web Table 28). While the foreign assets of the top 100 MNEs amounted to US\$1.3 trillion in 1993 (UNCTAD, 2007, p. 7), they had risen to US\$ 4 trillion in 2003 (UNCTAD, 2005, Table I.4, p. 17), and to US\$ 8 trillion in 2013, accounting that year for 59 percent of the firms' total assets. ${ }^{63}$ What is important to note in this context is also that firms from emerging markets ${ }^{64}$ have become important players in the world FDI market: of the 100,000 plus MNEs, some 30,000 are headquartered in emerging markets (UNCTAD, 2012, web Table 34).

There are, of course, strong arguments in favor of the current process of global micro-rulemaking:

- Rules are established only if and when there is a clearly defined need, often in response to specific occurrences or in response to a series of crises. Hence, the partial nature of the emerging frameworks reflects real priorities. To put it differently: if the need for international rules in a particular subject area is strong enough, rules will emerge, and they will be implemented and adapted. It is essentially a market- and demand-driven process based on trial and error, involving also a certain amount of regulatory competition. Moreover, the making of rules on a particular issue can begin at the national level and then be expanded to a region (including through mutual recognition and open codes) and eventually be multilateralized. This, for example, happened in the area of corruption. ${ }^{65}$

- The same arguments apply to the uneven geographical coverage of rules. There may be no urgent need to cover all countries if they play only a marginal role in a given area or if some countries want to pursue different approaches. In any event, consensus on truly multilateral rules is difficult to obtain in a world of some 200 jurisdictions.

- In line with the argument that rules ought to be established only if and when they are clearly needed, rules should also only be established by those who need them most (with others free to join in). This is also in line with the subsidiarity principle (i.e., decisions should be made at the most local level practicable). It moreover ensures that rules are adopted relatively quickly when needed (as contrasted with the typically cumbersome multilateral process), and they can be adapted relatively quickly. (The Uruguay Round of Multilateral Trade Negotiations took some eight years to complete; during that time, computer chips roughly doubled their capacity every 18 months, and the Internet was born. WTO's Doha Round, launched in 2001, was still ongoing in 2015.) 
- And, of course, the current process of rule-making reflects the reality of power, as rules are often also a tool for exercising power and obtaining advantages. To put it differently, why should the countries and governments that benefit most from the current approach agree to a different approach? To give an example, why would the United States agree to restrict the global influence of "its" rating agencies in favor of a multilateral approach? Or, if, say, the accounting standards of one country or one group of countries become the global rules, the accounting firms grounded in the respective rules obtain a competitive advantage.

These considerations are important. They reflect the reality - and rationale -- of the global micro-regulatory frameworks that are actually emerging. These frameworks react to perceived needs, are market-driven and are largely voluntary in nature. And they reflect the reality that economic and business globalization has out-paced the political and social organization of states and societies.

However, there is an alternative approach - a more systematic one that deliberately seeks to identify emerging needs and addresses them before major costs have been incurred. (Braithwaite and Drahos capture the two approaches, in their ideal form, instructively in Figure 2, under the headings "top-down" and "bottom up".) It is a systematic, government-driven, regulatory approach, an approach that was pursued when the international trade regime was created. ${ }^{66}$ After all, it should not be necessary for a series of spectacular corporate governance failures to occur before corrective actions are taken - perhaps in the heat of the moment, but with world-wide implications. Similarly, it should not be necessary, for example, for a series of spectacular bankruptcies of large MNEs to take place before a multilateral approach to this issue is agreed upon. In the context of growing interdependence, the costs of any crisis or major event are increasingly no longer confined to the countries engulfed in a particular crisis or in which a major event has taken place; rather, the costs are likely to spread to others, with, at times, potentially systemic implications.

A more systematic process can move at deliberate speed and explicitly encompass both the public and private sectors (and, for that matter, other stakeholders that are affected by a particular issues) in order to ensure that a proper balance between public and private interests is found. This consideration also suggests the desirability of broad participation by representatives of governments and businesses (and other groups) from developed and developing countries. Such a process would furthermore enhance the legitimacy of the rules being established and hence contribute to their overall acceptance - and the legitimacy of any framework depends, in the long run, on its capacity to reflect broad acceptance by those that are affected by it. ${ }^{67}$

A good part of the emerging micro-regulatory frameworks is indeed open to criticism when it comes to the question of who formulated the rules and what is the proper balance of public vs. private interest. This, in turn, is likely to raise, sooner or later, questions about their legitimacy - a challenge that can only intensify as the importance of micro-rules, their nature, their contents, and the costs of their absence become more apparent, and the weight of countries that were not involved in their formulation increases. This is not the fault of those engaged in the construction of the micro-regulatory frameworks so far: typically, they are the ones who have felt the most pressing need and have responded to it to the best of their ability. Besides, what has been achieved in this manner is noteworthy and important, and it facilitates the functioning of global markets and the integrated international production system. It is the natural response to the emergence of something new, the shape, magnitude and characteristics of which are still vague and evolving, and which takes place at a time when governments still focus on macro-liberalization. 
Top-down

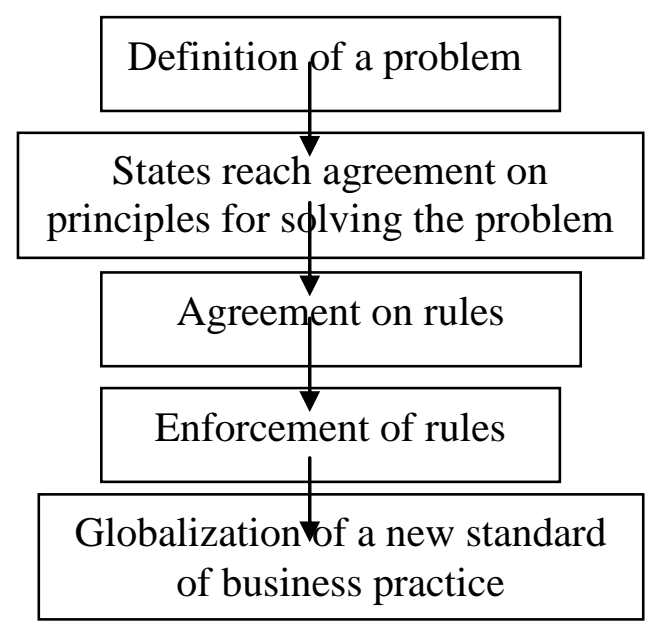

Bottom-up

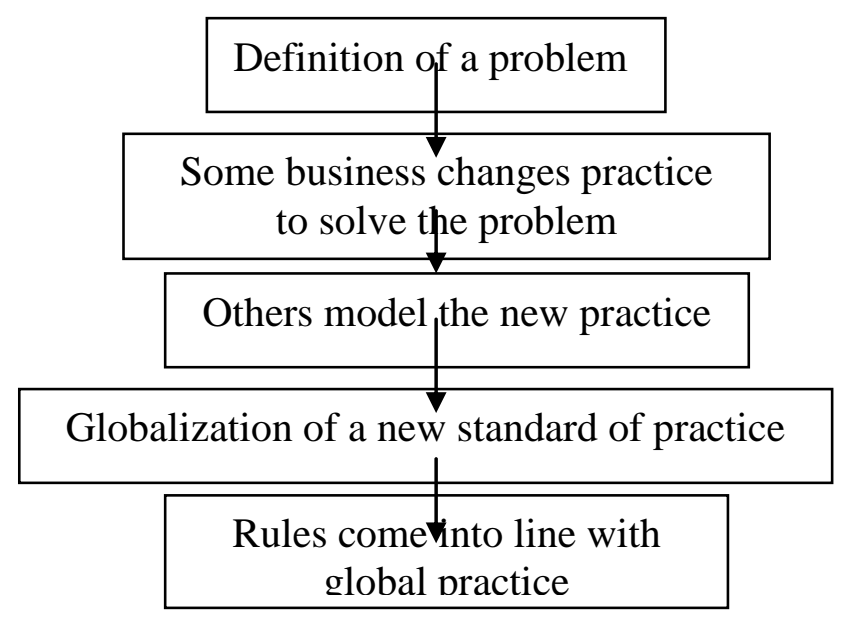

Figure 2. Top-down and bottom-up globalization of regulation.

Source: Braithwaite and Drahos, 2000, p. 554.

However, by now the reality of an integrated international production system and global markets is upon us, and more attention needs to be given to the micro-regulatory infrastructure of the globalizing world economy. The logic of globalization suggests that governments now need to give more attention to a systematic process of identifying and addressing new needs, as opposed to dealing with such needs only after they have manifested themselves (repeatedly, and negatively). This would amount to an extension of the systematic process that, over the past 60 years, has characterized macro-rule making, to the micro-issues. The issue is not to replace macro with micro rule-making; rather the issue is to shift the balance more to the latter. In the end, the key challenges are efficiency, the proper balance between private and public interests and, ultimately, legitimacy. ${ }^{68}$

\section{HOW TO SET THE NEW AGENDA?}

With micro-regulatory issues coming to the forefront, the nature of the current process of global micro-rule-making needs to be reviewed, at least as far as three dimensions are concerned:

- What are the micro-issues that require international attention? Which among them are particularly urgent? Which have interested constituencies that could move an issue forward? Which issues are most likely to be ripe for consensus, at least about basic principles? And, from a development perspective, which are particularly important for developing countries and their firms? Equally important, there are such questions as: how does trade and investment deregulation mesh with increasing micro regulation? When are global rules important? When do voluntary arrangements work? When do they fail and why? How do we determine which global rules have persisted and which have languished? When are global rules impossible to enforce, because of the lack of global enforcement mechanisms? Do global rules have to be accepted within nation states to become effective, implying that the last word remains with individual governments? What is the best way to involve various stakeholder groups? The establishment of such a list of issues and questions is, in many ways a very technical task. It would involve a systematic examination of a broad range of issues that, due to the emergence of global markets and an integrated international production system, are increasingly difficult to address effectively in a purely domestic context. Some of these issues may well overlap and/or may interact and/or may involve a sequencing in terms of action that needs to be taken. It would be a stock-taking exercise which, at a 
minimum, could serve as an early warning system to draw attention to issues that require an international approach. ${ }^{69}$

- How should priority issues be addressed in terms of form and content? Presumably, when the priority issues requiring an international approach are identified, the grounds for priorities would be explained as well. It would also be logical to suggest, at the same time, options for how these issues should be addressed internationally, including how any rules could be implemented and enforced. As to form, the earlier discussion has shown that there are many ways in which issues can be addressed internationally, ranging from business or industry arrangements to mixed business-government actions to regional agreements among governments to international codes, and to multilateral treaties negotiated in the appropriate fora. ${ }^{70}$

- Who should identify the priority issues and suggest options as to how they could be addressed? Obvious candidates to take the lead are think tanks or research institutions, a blue-ribbon commission or an international organization.

When it comes to actual rule-making, the WTO may be a strong candidate. The WTO and, in particular, its predecessor, the GATT, have shown that substantial achievements are possible at the multilateral level. Moreover, the WTO has a broad remit, and it has already made some timid and tentative steps in the direction of dealing with micro-issues. Thus, the outcome of the Uruguay Round included a Ministerial Decision on Professional Services that provided: "As a matter of priority, the Working Party [on Professional Services] shall make recommendations for the elaboration of multilateral disciplines in the accountancy sector...."71 On conclusion of the negotiations on the accountancy disciplines in December 1998 (WTO, 1998), the WTO's Services Council established a Working Party on Domestic Regulation, whose mandate included to "develop disciplines as appropriate for individual sectors or groups thereof.,"72 Moreover, the WTO's work in the area of telecommunications, through the formulation of its "Telecommunication Reference Paper,"73 is relevant here. This document, drafted on an informal basis by a group of like-minded WTO members and finalized in 1997, contains a set of regulatory principles/standards for the regulation of telecommunication service providers. WTO members individually agreed upon it as containing binding commitments, and these were subsequently incorporated in the schedules of new accession countries as additional commitments. This may be one approach to move the micro-regulatory agenda forward. Indeed, this is the approach taken regarding some of the new issues that are being discussed in the new generation of services-trade agreements, for instance, on the governance of the internet (data flows, privacy, data confidentiality, etc.).

UNCTAD could also be a candidate, especially if the idea is to pay special attention to the needs of developing countries. UNCTAD, too, has ventured - at least to a certain extent - into the area of micro-issues, for example, through its Intergovernmental Working Group of Experts on International Standards of Accounting and Reporting, established in $1982 .{ }^{74}$ For, as observed earlier, developing countries and their firms (including state-owned enterprises) tend to be rule-takers and not rule-makers in the area of micro-regulation, and the interests of their firms thus need special attention.

Finally, there are many specialized fora dealing with specific aspects of the international operations of firms, some of them mentioned earlier in this chapter. 
Depending on their interests, they might be able to advance the discussion in specific fields. Special attention would need to be given to the ability of an organization to be able to react swiftly to changing circumstances, as there is the danger that, in a world of rapid innovations and changes, rules formulated by governments could be out of date by the time they are adopted. ${ }^{75}$

Regardless of who takes the lead, it is clear that the effort needs to involve all major stakeholders, particularly representatives from governments and businesses from developed and developing countries, but also from other parts of civil society, including trade unions, consumer organizations and other non-governmental organizations (NGOs) ${ }^{76}$ The reason for government representatives is clear: after all, a good part of the emerging global micro-regulatory frameworks will (eventually) consist of governmental arrangements; even more importantly, governments represent the public interest. Representatives of the business community are crucial because, after all, they are best placed to know what the key issues are and how they could be addressed. The involvement of all major stakeholders would also lead to a situation in which the process of creating micro-regulatory frameworks would not be either government-led and systematic, leading to mandatory instruments, or market-driven and ad hoc, leading to voluntary instruments, but rather result in a mixed approach that combines the interests and expertise of all major stakeholders.

But the question of the participation of businesses, trade unions, consumer organizations, and other NGOs is broader than the expertise and interests specific groups might represent and bring to the table. Input by various stakeholders into international rule-making is a logical consequence of the globalization process and the strengthening of global institutions: in the same manner in which businesses, trade unions, consumer organizations, and other NGOs seek to influence rule-making at the national level, they will more and more seek to influence rule-making at the international level as well; and, the more important these rules are, the more they will seek to do so. If this cannot be done in a transparent institutional context, it will be done through the back door or in the streets. The only way to avoid increased interest by these groups in global rule-making is to reduce the relevance of such rule-making and of the institutions in which it takes place which is precisely the opposite of what global markets and an integrated international production system need. To be sure, this makes global rule-making even more complicated - but it also opens new opportunities for alliances, open or tacit ones. ${ }^{77}$

Still, greater participation by businesses, trade unions, consumer groups, and other NGOs is easier said than done, and it will require institutional innovations to increase transparency and establish appropriate mechanisms. In any event, and independently of the mechanisms eventually established, nothing prevents whoever takes the lead in this matter from ensuring that all major stakeholders can provide their inputs on priority issues for the global agenda for micro-regulatory issues.

In conclusion, the advanced state of macro-liberalization and rule-making for international economic transactions at the level of countries shifts the focus to a new frontier: the need to establish micro-regulatory frameworks - and hence the regulatory infrastructure and rules of the road - for the various operations of firms in the globalizing world economy. These rules would constitute the governance of the international operations of firms in the globalizing world economy. The current ad-hoc and marketdriven process can be made more efficient, more likely to achieve a better balance between public and private interests, and ultimately more legitimate. Such a process could involve, in the first instance, the systematic identification of issues requiring an international approach, as well as the identification of options for how to address them, in a process that involves all major stakeholders. Such a process, ambitious as it would be, would amount 
to setting an agenda for the development of global micro-regulatory frameworks for various aspects of the international operations of firms in the globalizing world economy and, hence, its global governance as far as the operations of firms are concerned. It would be the agenda for the next generation of global commercial rule-making. Pursuing such a process would involve going forward pragmatically, beginning with issues on which consensus might be easiest to achieve, in a piece-meal approach, focusing on subjects for which constituencies can be mobilized to advance the process, in whatever organizational framework is most appropriate. ${ }^{78}$

While the process that is being suggested here seeks to be a rational one, it is unavoidably also a profoundly political one, in at least two senses: it involves the old question of how best to balance the role of the state and the market; and it sets the stage for determining, in Harold D. Lasswell's (1936) classic definition of politics: "who gets what, when, how" in the globalizing world economy.

\section{NOTES}

* Karl P. Sauvant (karlsauvant@gmail.com) is Resident Senior Fellow, Columbia Center on Sustainable Investment, a joint center of Columbia Law School and The Earth Institute at Columbia University, New York. He was the Founding Executive Director of the predecessor of that Center, the Vale Columbia Center on Sustainable International Investment, and Director of UNCTAD's Investment Division. The author thanks Mira Wilkins and two anonymous peer reviewers for their very helpful feedback, as well as Rudolf Adlung, Maria Cattaui, Andrew Cornford, Persa Economou, Michael Finger, Torbjorn Fredriksson, Masataka Fujita, Vishwas Govitrikar, John Kline, Aik Hoe Lim, Padma Mallampally, Herbert Oberhaensli, Pedro Roffe, Lorraine Ruffing, Peter Walton, and Lou Wells for very helpful comments on earlier versions of this chapter, and Matthieu Wharmby, Valantina Amalraj and Vetan Kapoor for their research assistance. All errors are of course those of the author's.

${ }^{1}$ This is exemplified by the negotiations of the Transatlantic Trade and Investment Partnership, in which regulatory harmonization is a key challenge. Behind-the-border issues are particularly important in the services sector where regulation often restricts market access. For a discussion, see Lim and Meester, 2014.

${ }^{2}$ This list can easily be expanded, e.g., by adding such issues as data flows, privacy, data confidentiality, carbon emission trading, dumping of harmful waste, minimum product quality standards, liability issues, enforcement of all sorts of contracts, and money laundering.

${ }^{3}$ See the G-20 "Communiqué", Meeting of Finance Ministers and Central Bank Governors, February 22-23, 2014, para. 9, available at https://www.g20.org/sites/default/files/g20_resources/library/Communique\%20Meeting\% 20of\%20G20\%20Finance $\% 20$ Ministers $\% 20$ and $\% 20$ Central\%20Bank $\% 20$ Governors $\% 20 \mathrm{~S}$ ydney\%2022-23\%20February\%202014_0.pdf, last visited April 8, 2015.

${ }^{4}$ In some respects, the discussion here is akin to Lorraine Eden's analysis of regulatory changes as a result of the formation of the North American Free Trade Agreement: "A shift in the overall regulatory environment is occurring in North America, away from unilateral rules to bilateral and trilateral policy-making. This shift can be seen in two ways: as a move away from weak/soft international regulation (non-binding commitments at the regional level) towards strong/hard international regulation (binding, formal rules and 
procedures); as a widening of the geographic scope of the regulatory environment from the national to the regional level." See Eden, 1996, p. 62.

${ }^{5}$ This article does not deal with products and processes, another important area in which global standards are increasingly becoming important. The International Organization for Standardization (ISO) is a leader in setting international standards; as of early 2015, it had a portfolio of 19,500 standards (see, http://www.iso.org/iso/home/standards.htm, last visited April 8, 2015). Even though ISO standards are voluntary, regulatory bodies have adopted a number of them, or they have become de facto standards. For a discussion, see, A. T. Kearney, 2012, and FIPRA, 2010.

${ }^{6}$ Information provided by Michael Finger. Tariff reductions were agreed upon in rounds of trade negotiations. During the Uruguay Round (1986-1994), most-favored-nations tariff reductions of developed countries for industrial products (excluding petroleum) amounted to 38 percent; in the preceding Tokyo Round (1973-1979), they amounted to 33 percent. See WTO, 2007, p. 207. The WTO concluded: "Industrial countries have substantially reduced their tariffs since 1947. Only in a few categories can they still be considered a significant trade barrier" (ibid., p. 210).

${ }^{7}$ To illustrate: between 1991 and 2001, some 95 percent of the policy changes in national regulatory regimes for FDI were in the direction of creating a more favorable environment for investment by MNEs (UNCTAD, 2002, p. 7) although that percentage had declined to 70 percent by 2013 (UNCTAD, 2014, p. 106), the bulk of policy changes still goes in the direction of making the investment climate more favorable for international investors.

The convergence toward similar (liberal) FDI regimes was aided by an explosion of bilateral investment treaties that strengthened the protection of foreign investment and facilitated access to markets; the number of bilateral investment treaties alone rose from 385 at the end of the 1980s (UNCTAD, 2000, p. 1) to 2,902 at the end of 2013 (UNCTAD, 2014, p. 114); to that, other international treaties covering international investment, numbering 334 by the end of the same year, need to be added. In fact, international investment agreements have become so widespread and strong, especially regarding the treatment of investors in the post-establishment phase of a project, that even a multilateral framework - if and when one should be negotiated - may do little more, at least initially, than lock in the autonomous and bilateral liberalization measures taken by many countries, which would increase predictability, stability and transparency.

${ }^{8}$ See, e.g., the various editions of OECD, WTO and UNCTAD, "Reports on G20 Trade and Investment Measures" available on the websites of these institutions.

${ }^{9}$ In principle, mode four of GATS covers labor mobility to a limited extent, as do various international investment agreements, but little has been achieved in practice.

${ }^{10}$ For a listing of the largest 100 MNEs from developing and transition economies, ranked by foreign assets in 2012, see UNCTAD, 2014, Annex Table 29, available at http://unctad.org/en/pages/DIAE/World\%20Investment\%20Report/Annex-Tables.aspx, last visited April 8, 2015.

${ }^{11}$ See the annual editions of the World Investment Report prepared by UNCTAD.

${ }^{12}$ In fact, a portfolio of locational assets is now an important source of corporate competitiveness in all sectors (UNCTAD, 1995; Dunning, 1996, 2002).

${ }^{13}$ The possibility of splitting up the production of services extends also to the various functions that are traditionally performed by corporate headquarters, ranging from communications to finance. They too can be located wherever it is best from the perspective of firms as a whole, disassembling what once were unified headquarters. 
${ }^{14}$ The emergence of such complex networks makes it difficult at times to identify the boundaries of a particular firm or, for that matter, to determine its nationality and any liabilities in case of, for instance, gross negligence.

15 These developments also create challenges for international investment and trade statistics. These have always been difficult to interpret, given that countries do not necessarily follow the reporting guidelines provided by the IMF, UNCTAD and the OECD. More recently, moreover, the rise of special-purpose entities has become a major issue, as these entities serve primarily the purpose of managing the liquid assets of MNEs by channelling investment flows from one country to another; in other words, these flows do not reflect productive investment in the reporting host countries. Such entities can be located in any country. Moreover, firms from a number of countries (including Brazil, China and Russia) channel a substantial share of their FDI flows through tax havens or financial centres. Finally, round-tripping continues to present a statistical problem. Fortunately, UNCTAD and the OECD have begun to receive data from countries that host special-purpose entities (e.g., Luxembourg, Hungary and the Netherlands) and to correct the data accordingly, also for tax havens (especially in the Caribbean). However, this correction does not yet cover all countries and distortions. They have therefore recommended that all countries report data with and without special-purpose-entity transactions. (For a discussion, see, OECD, 2015.) Note, however, that these corrections would lead to more accurate FDI statistics on the basis of the traditional balance-ofpayments approach to such statistics. These corrections would not capture, for example, FDI made on the basis of MNEs raising funds in the financial markets of host countries or in international financial markets outside their home countries. Moreover, these corrections would also not capture non-equity forms of control utilized by firms in regard to enterprises located abroad. Hence, FDI data substantially underestimate the share of production under the common governance of MNEs.

${ }^{16}$ Traditionally, international rules are made by governments for other governments; in a sense, this process involves rules about rules. International rules that apply directly to firms (while not unheard of) have not been the domain of traditional trade policy. Moving in that direction requires a paradigm change in international law.

17 This is not a new phenomenon. U.S. firms started to move abroad from the midnineteenth century onwards; by 1914, practically all innovative and important firms had global operations, typically operating on a stand-alone basis. See Wilkins, 1970.

${ }^{18}$ The focus of this chapter is on the activities of firms, regardless of industry, although some of the examples below are industry specific. The same argument can be made for labor-related, environmental, consumer, and other matters. In fact, when it comes to the social dimension of globalization, it could be argued that, just as economic growth in many developed countries was facilitated by (and indeed may have required) a national social consensus, world economic growth would benefit from a world social consensus as well precisely the idea underlying the Global Compact (Kell and Ruggie, 1999).

${ }^{19}$ See, e.g., the Transatlantic Trade and Investment Partnership, in which regulatory harmonization is one objective. See also the nascent efforts in the World Trade Organization discussed briefly below.

${ }^{20}$ But see, e.g., Braithwaite and Drahos, 2000. The focus is here on corporate activity. There have, of course, been various (successful) efforts to establish global standards in such areas as defining time zones, the measurement of lengths and distances, etc. These types of arrangements are not considered here.

${ }^{21}$ In a number of countries, furthermore, incoming M\&As may be reviewed on the basis of national security considerations. 
${ }^{22}$ In 2001, GE abandoned its plan to acquire Honeywell. Although U.S. regulators had approved the deal, the European Commission objected and the deal did not take place.

${ }^{23}$ Annex to UNCTAD, 2015, web Table 9.

${ }^{24}$ Ibid., web Table 11.

25 "Perhaps the most effective model of international cooperation in merger control currently is the EU's 'one-stop shop,' which allows parties to avoid multiple filings in the EU by submitting a single notification to the European Commission. Even this system, for all its merits, is far from flawless: many hundreds of transactions are still notified in more than one EU country each year." See, Squire Sanders, 2012.

${ }^{26}$ For example, U.S. law traditionally defers to foreign home jurisdictions in bankruptcy matters. As a consequence, U.S. victims of Polly Peck's securities fraud could not seek recovery in the United States (Boshkoff, 1994, pp. 935-936).

${ }^{27}$ UNCITRAL's Model Law on Cross-border Insolvency, which seeks to encourage international cooperation, was adopted in 1997. See, UNCITRAL, available, at http://www.uncitral.org/uncitral/en/uncitral_texts/insolvency/1997Model.html, last visited April 8, 2015.

${ }^{28}$ Basel Committee on Banking Supervision, "About the Basel Committee", available at http://www.bis.org/bcbs/about.htm, last visited April 8, 2015.

${ }^{29}$ The Basel Committee consists of representatives from central banks and/or supervisory authorities from 27 jurisdictions: Argentina, Australia, Belgium, Brazil, Canada, China, France, Germany, Hong Kong SAR, India, Indonesia, Italy, Japan, Korea (Republic of), Luxembourg, Mexico, the Netherlands, Russia, Saudi Arabia, Singapore, South Africa, Spain, Sweden, Switzerland, Turkey, the United Kingdom, and the United States plus the European Central Bank See, Basel Committee, available at http://www.bis.org/bcbs/, last visited April 8, 2015.

${ }^{30}$ Basel Committee on Banking Supervision (BCBS) Charter, op. cit., section V (12).

${ }^{31}$ BCBS, 2014, p. 8. It needs to be recognized, however, that compliance with Basel III (and, for that matter, Basel II) is not uniform, as "internationally active" is not a welldefined term. The incorporation of Basel II and Basel III in national rules typically covers different sets of banks differently. Moreover, Basel II and Basel III do not consist of uniform sets of rules, but include options, typically for banks with different business models and at different levels of technical sophistication.

${ }^{32}$ Caliskan and Cochran, 2003, pp. 1-3.

33 "The European Union addressed the issue of CRS well before ICAO. The Council of the European Communities issued, on 24 July 1989, Council Regulation (EEC) No. 2299/89 on a code of conduct for computerized reservation systems. The regulation applies with the force of law to computerized reservation systems for air transport products, when offered for use and/or used in the territory of the Community, and their essence is to provide equal access and non-discrimination. A revised version of the Regulation is contained in Regulation (ERC) No. 323/1999 that entered into force on 15 March 1999" (Milde, 2008, p. 115). See Council Regulation (EEC) No. 2299/89, available at http://eurlex.europa.eu/legal-content/EN/TXT/?uri=CELEX:31989R2299, last visited April 8, 2015. ${ }^{34}$ This absence of a multilateral solution is due in part to the strategic importance of national airlines in many countries, and to their double nature as both commercial service providers and public utilities (Abeyratne, 2005-2006, p. 50).

${ }^{35}$ Regarding CRS regulation for example, the ICAO issued a Code of Conduct on the Regulation and Operation of Computer Reservation Systems (CRS) and developed a model CRS clause to be used in bilateral and multilateral agreements. See ICAO, available at http://www.icao.int/sustainability/pages/eap_ep_crs.aspx, last visited April 8, 2015 ("the 
ICAO Council completed its review of the Code and adopted a revised version on 25 June 1996 with model clauses to encourage its use. As of 1 September 1998, twenty-nine ICAO Member States either followed the ICAO Code or had CRS regulations which are consistent or compatible with it").

${ }^{36}$ Consolidated accounts are an aggregation of financial statements of individual companies constituting a group. These companies keep a single set of accounts. In a consolidation, the lines from the statements of the individual companies are put together, making adjustments for double-counting, etc., and then amending them to the extent that local principles are not in accordance with the international rules. Part of the appeal of International Financial Reporting Standards (IFRS) is that, when MNEs can use IFRS in the books of their foreign affiliates, there are no adjustments necessary during consolidation.

${ }^{37}$ The Board has 14 members with accounting or finance background.

${ }^{38}$ The U.S. Financial Accounting Standards Board has seven members with expertise in accounting, finance and business. It is controlled by the Financial Accounting Foundation and advised by the Financial Accounting Standards Advisory Council with 34 members who are broadly representative of preparers, auditors and users of financial information. Members of the U.S. Financial Accounting Standards Board and the Financial Accounting Standards Advisory Council are nominated by the Board of Trustees made up of 16 members representing constituent organizations having interest in financial reporting; see FASB, "Board Members," available at http://www.fasb.org/jsp/FASB/Page/SectionPage\&cid=1218220131802, last visited April 8, 2015; FAF, "FAF Trustees and Committees," available at http://www.accountingfoundation.org/jsp/Foundation/Page/FAFLandingPage\&cid=11761 64681018, last visited April 8, 2015.

39 IFRS Foundation, "Analysis of the IFRS Jurisdictional Profiles", available at http://www.ifrs.org/Use-around-the-world/Pages/Analysis-of-the-IFRS-jurisdictionalprofiles.aspx, last visited April 8, 2015. It should be noted, however, that not all countries adopt all the standards, and not all public companies in these countries have to use these standards. On the other hand, this is not uncommon, even within countries; for example, the U.S. Generally Accepted Accounting Principles are not applied uniformly across the United States. Both sets of standards allow for choices in some cases.

${ }^{40}$ There were 940 non-U.S. companies registered and reporting to the U.S. Securities and Exchange Commission (SEC) as of December 31, 2014; see, SEC, available at http://www.sec.gov/divisions/corpfin/internatl/companies.shtml, last visited April 8, 2015.

41 The Economist, May 9, 2012. Though the International Financial Reporting Standards are largely based on the U.S. standards, the SEC does not allow U.S. companies to use only the international standards. The sector's regulatory segmentation coincides with high access barriers to the profession in many countries.

${ }^{42}$ The members of the Association account for $97 \%$ of the world's insurance premiums. See the Association's website, available at http://www.iaisweb.org, last visited April 8, 2015.

${ }^{43}$ As far as trade in food products is concerned, the Codex Alimentarius seeks "to ensure safe, good food for everyone, everywhere" through international food standards, guidelines and codes of practice; see, http://www.codexalimentarius.org/codex-home/en/, last visited April 8, 2015.

${ }^{44}$ For example, a French court failed to prohibit Delaware-based Yahoo! from selling Nazi memorabilia to French consumers online. A U.S. District Court in California issued a 
declaratory judgment that ruled that the French order could not be enforced in the United States (Stewart and Matthews, 2002, pp. 1116-1118).

${ }^{45}$ In particular, U.S. authorities have disagreed with the European Union's approach that enables consumers to sue in their country of habitual residence (Stewart and Matthews, 2002, pp. 1119-20).

${ }^{46}$ On July 1, 2014, the French bank BNP Paribas (BNPP) pleaded guilty to processing billions of dollars of transactions through the U.S. financial system on behalf of sanctioned entities. BNP hence acknowledged that it processed disguised transactions for Cuban, Iranian and Sudanese entities in violation of the International Emergency Economic Powers Act and the Trading with the Enemy Act (Zagaris, 2014).

${ }^{47}$ In 2007, for example, Cuban officials were denied a room in a Norwegian hotel of the United States-based Hilton hotel chain. Hilton did not want to take the chance of violating the Trading with the Enemy Act. On the other hand, the Norwegian hotel faced a legal complaint in Norway for discriminating on the basis of citizenship. Similarly, in 1997, a Canadian subsidiary of Wal-Mart stopped selling Cuban pajamas when faced with potential sanctions under the U.S. Trading with the Enemy Act. Canadian authorities, however, ordered the product back on its shelves in the name of the country's Foreign Extraterritorial Measures Act, a national law barring enforcement of non-Canadian trade laws incompatible with Canada's trade interests (Rathbone et al., 2013, pp. 1072, 11201122).

${ }^{48}$ Of course, this is an extremely sensitive issue, as also reflected in the leeway provided under GATT Art. XXI and GATS Art. XIVbis.

${ }^{49}$ The rules apply to domestic or foreign airline-affiliated computer reservation systems "used by travel agencies in the U.S." (Leaming, 1993, p. 495).

50 UNCITRAL, "Model Law on Cross Border Insolvency, Status", available at http://www.uncitral.org/uncitral/en/uncitral_texts/insolvency/1997Model_status.html, last visited April 8, 2015.

${ }^{51}$ See, 11 U.S.C. $§ 1501$. See also United States Courts, "Chapter 15: Ancillary and Other Cross-Border Cases", available at http://www.uscourts.gov/FederalCourts/Bankruptcy/BankruptcyBasics/Chapter15.aspx, last visited April 8, 2015.

52 See, IFRS Foundation, "About Us," available at http://www.ifrs.org/Aboutus/Pages/Monitoring-Board.aspx, last visited April 8, 2015. "Through the Monitoring Board, securities regulators that allow or require the use of IFRS in their jurisdictions will be able to more effectively carry out their mandates regarding investor protection, market integrity, and capital formation." See, http://www.ifrs.org/About-us/Pages/MonitoringBoard.aspx", last visited April 10, 2015.

${ }^{53}$ See, http://iaisweb.org/index.cfm?event=getPage\&nodeId=25181, last visited April 8, 2015.

54 ILO, "Mission and Objectives", available at http://www.ilo.org/global/about-theilo/lang--en/index.htm, last visited April 8, 2015. Note, however, that ILO conventions commit only the countries that have actually ratified them, but they cannot be enforced.

${ }^{55}$ Komori and Wellens, 2013. Partly this is the case because the Committee's agenda deals primarily with longstanding problems that have become apparent in the Committee's more developed members or that have arisen in the context of the recent financial crisis (which involved primarily developed countries).

${ }^{56}$ In some of these instances, rule-making may take place through a "club approach", as developed by Eden and Hampson for the cooperation of states to capture benefits of 
cooperation, whereby clubs "should be viewed as dynamic institutions whose membership may well change over time". See Eden and Hampson, 1997, p. 380.

${ }^{57}$ OECD, International Investment and Multinational Enterprises (Paris: OECD, 2011), available at http://www.oecd.org/daf/inv/investmentpolicy/oecddeclarationoninternationalinvestmentandmultinationalenterprises.htm, last visited April 8, 2015. As of early 2015, all 34 OECD member countries and 12 non-OECD members had adhered to the Guidelines.

58 See, e.g., ILO, 1977; and UNCTAD, 1980; see United Nations document TD/RBP/CONF/10/Rev.1 (1981).

${ }^{59}$ See, the "Guiding Principles on Business and Human Rights," 2011.

${ }^{60}$ To the extent that these frameworks are beginning to be formulated in the context of bilateral or regional trade agreements, it may well be that a few dominant players effectively pre-empt any future multilateral initiatives.

${ }^{61}$ See, e.g., the response of the G20 to the question of tax avoidance by MNEs, G20, 2014, p.2.

${ }^{62}$ In terms of the absolute value of their assets abroad.

${ }^{63}$ UNCTAD, 2014, p. 32. In 2013, 57 percent of employment of the top 100 was located abroad.

${ }^{64}$ Basically all non-OECD countries.

${ }^{65}$ In reaction to a series of scandals, the United States adopted the Foreign Corrupt Practices Act in 1977. As this Act was seen to put U.S. firms at a disadvantage vis-à-vis firms headquartered in other countries when engaging in business abroad, the country's government sought to multilateralize its approach to illicit payments. Accordingly, it succeeded in launching negotiations in the United Nations on an international agreement on illicit payments. However, when the Draft International Agreement on Illicit Payments (available

at unctad.org/Sections/dite_tobedeleted/iia/docs/compendium/en/9\%20volume\%201.pdf, last visited April 8, 2015) was put before the General Assembly in 1979, that body took no action since neither the developing countries, nor other developed countries were supportive of such an instrument. However, the issue was later addressed in the OECD and led to the adoption of the "Convention on Combating Bribery of Foreign Public Officials in International Business Transactions," which entered into force on February 15, 1999 (available at http://www.oecd.org/daf/anti-bribery/ConvCombatBribery_ENG.pdf, last visited April 8, 2015). The issue returned to the United Nations, where the United Nations Convention against Corruption was eventually adopted by the General Assembly on October 31, 2003; it entered into force on December 14, 2005 (available at http://www.unodc.org/documents/treaties/UNCAC/Publications/Convention/08-

50026_E.pdf, last visited April 8, 2015).

${ }^{66}$ One difference might be that, when the trade regime was created, there was broad agreement on the principles governing trade, an agreement that is still largely absent regarding the micro-regulatory issues discussed here. At the same time, though, the need to close the governance gap is recognized from time to time, e.g., when governments took action on corruption and tax avoidance.

${ }^{67}$ There is of course the challenge that many countries - but by far not all - have limited capacity to participate in such rule-making processes. And there are of course other challenges. For example, who would decide on who is entitled to represent legitimate (social, environmental, commercial, prudential, etc.) interests? Would these interests first be balanced in a national context or could they be pursued immediately at the international level? How could the more economically powerful states/unions/business 
associations/non-governmental organizations be prevented from setting the agenda? What would be the appropriate forum?

${ }^{68}$ There are some indications that a more systematic approach is already being adopted, especially in the social and environmental areas. Social and environmental issues have moved far in terms of a systematic process, partly because of support from strong constituencies (labor unions and environmental groups), partly because of their inherently global nature and partly because the need for a systematic process was recognized.

${ }^{69}$ Although the focus of this article has been on business issues, such an exercise could also include related matters, such as environmental and social issues, as these are closely linked to, if not an inextricable part of, the economic globalization process.

${ }^{70}$ It needs to be recognized that the negotiation of global micro-rules would place a great burden on developing countries, many of which are still seeking to implement the agreements negotiated in the context of macro-liberalization. But the alternative - to leave the determination of such rules to others - carries the risk that the interests of the developing countries (or, more precisely, of their firms) would be ignored; this, in turn, would eventually raise legitimacy concerns.

${ }^{71}$ Final Act of the Uruguay Round of Multilateral Trade Negotiations (April 1994), "Decision on Professional Services," para. 2, available at http://www.wto.org/english/docs_e/legal_e/51-dsprf_e.htm (last visited January 12, 2015). The job description of one of the 18 new posts that were created at that time referred to expertise in accounting - a far cry from what most people think the WTO is all about, but perhaps indicative of what that organization may increasingly be about in the years to come.

${ }^{72}$ WTO, 1999, para. 3. It should be noted, however, that the WTO domestic regulation negotiations do not seek to define the micro-regulatory framework for the globalizing world economy but rather aim at curbing protectionist and anti-competitive behavior, by establishing rules to ensure that regulations do not constitute unnecessary barriers to trade in services. In other words, the rules sought by the WTO are not prescriptive for the content of regulations nor do they seek to harmonize regulations or set standards, leaving that to regulators/governments. (See, Lim and De Meester, op. cit.)

${ }^{73}$ The Telecommunication Reference Paper was never formally adopted. But many of the WTO's new members, as well as those that negotiated it initially, incorporated it into their commitments. See, e.g., WTO, 2013.

$74 \quad$ See, http://unctad.org/en/Pages/DIAE/ISAR/ISAR-Corporate-TransparencyAccounting.aspx, last visited December 17, 2014. For a review of the work of this Working Group, see Ruffing, 2015.

${ }^{75}$ See, for example, the situation concerning commercial drones where innovation appears to be far ahead of even national rules governing their utilization.

${ }^{76}$ Reference was made earlier to the Codex Alimentarius. By way of example, the Codex Alimentarius Commission had, as of March 2015, 186 members and 229 observers, including a number of business organizations, consumer groups and other NGOs; furthermore, the Codex meetings are public. See, http://www.codexalimentarius.org/members-observers/en/, last visited April 3, 2015.

${ }^{77}$ An example of a tacit alliance between a number of governments and NGOs was the effort on access to medicines that led to the adoption, during the 2001 Doha WTO ministerial meeting, of a resolution concerning the interpretation of the TRIPS Agreement. ${ }^{78}$ In some ways, such a process is reminiscent of the approach taken to advance European integration; see Haas, 1964. 


\section{REFERENCES}

Abeyratne, Ruwantissa, "Competition in Air Transport: The Need for a Shift in Focus", Transportation Law Journal, 33 (2005-06), pp. 29-110.

Altman, Jamie, "A Test Case in International Bankruptcy Protocols: The Lehman Brothers Insolvency”, San Diego International Law Journal, 12 (2010-11), pp. 463-496.

“Accounting Standards: Eternal Convergence", The Economist, May 9, 2012.

A.T. Kearney, "Business Implications of Standard Setting", prepared for the European Round Table of Industrialist, April 2012.

Braithwaite, John and Peter Drahos, Global Business Regulation (Cambridge: Cambridge University Press, 2000).

Basel Committee on Banking Supervision, Report to G20 Leaders on monitoring implementation of Basel III regulatory reforms (Basel: Basel Committee, August 2013).

Basel Committee on Banking Supervision, "Implementation of Basel Standards: A Report to G20 Leaders on Implementation of the Basel III Regulatory Reforms" (Basel: BIS, November 2014).

Bank for International Settlements, Principles for Sound Liquidity Risk Management and Supervision (Basel: Basel Committee, September 2008).

Bank for International Settlements, International Convergence of Capital Measurement and Capital Standards: A Revised Framework (Basel: Basel Committee, June 2004).

Boshkoff, Douglas, "Some Gloomy Thoughts Concerning Cross-border Insolvencies", Washington University Law Quarterly, 72 (1994), pp. 931-942.

Caliskan, Anil and Jay Cochran, III, Mercatus Center's Regulatory Program: Public Interest Comment on Computer Reservation Systems (Washington, D.C.: George Mason University, March 2003), pp. 1-3.

Cornford, Andrew, The Basle Committee's Proposals for Revised Capital Standards: Rationale, Design and Possible Incidence (Geneva: UNCTAD, 2000).

Dunning, John H., "The Geographical Sources of the Competitiveness of Firms: Some Results of a New Survey", Transnational Corporations, 5 (December 1996), pp. 130.

Dunning, John H. and Allison McKaig-Berliner, "The Geographical Sources of Competitiveness: The Professional Business Service Industry", Transnational Corporations, vol. 11 (December 2002), pp. 1-38.

Eden, Lorraine, "The emerging North American investment regime", Transnational Corporations, 5 (December 1996), p. 62. 
Eden, Lorraine and Fen Osler Hampson, "Clubs are trump: the formation of international regimes in the absence of a hegemon", in J. Rogers Hollingsworth and Robert Boyer, eds., Contemporary Capitalism: The Embeddedness of Institutions (Cambridge: Cambridge University Press, 1997), p. 380.

FIPRA, "Standard Setting in a Changing Global Landscape. Report to the European Round Table of Industrialists", October 2010, available at http://www.ert.eu/sites/default/files/Standard\%20setting\%20in\%20a\%20changing\% 20global\%20landscape\%20Final\%20Report_0.pdf, last visited April 8, 2015.

G20, "Communiqué, Meeting of G20 Finance Ministers and Central Bank Governors", p. 2, para. 8 (Cairns, September 20-21, 2014).

"Guiding Principles on Business and Human Rights: Implementing the United Nations 'Protect, Respect and Remedy Framework"' (Geneva: United Nations Human Rights Office of the High Commissioner, 2011).

Haas, Ernst B., Beyond the Nation-state: Functionalism and International Organization (Stanford: Stanford University Press, 1964).

Herring, Richard J., "BCCI and Barings: Bank Resolutions Complicated by Fraud and Global Corporate Structure." Paper presented at the Federal Reserve Bank of Chicago Conference "Systemic Financial Crises: Resolving Large Bank Insolvencies" (September 30-October 1, 2004).

ILO, "Tripartite Declaration of Principles Concerning Multinational Enterprises and Social Policy," adopted by the Governing Body of the ILO on November 16, 1977, available at http://www.ilo.org/public/english/employment/multi/download/english.pdf, last visited April 8, 2015.

IMF, International Financial Statistics (Washington: IMF, 2002).

IFRS Foundation Monitoring Board, Final Report on the Review of the IFRS Foundation's Governance (Madrid: IOSCO, February 9, 2012).

Johnson, Philip, "Enforcing Online Arbitration Agreements for Cross-Border Consumer Small Claims in China and the United States", Hastings International and Comparative Law Review, 36 (2013), pp. 577-602.

Kell, Georg and Gerard Ruggie, "Global Markets and Social Legitimacy: The Case of the 'Global Compact'", Transnational Corporations, 8 (December 1999), pp. 101-120.

Komori, Teruo and Karel Wellens, Public Interest Rules of International Law: Towards Effective Implementation (Farnham: Ashgate Publishing, Ltd., 2013).

Lasswell, Harold D., Politics: Who Gets What, When, How (New York: Peter Smith, 1936). 
Leaming, Marj P., "Enlightened Regulation of Computerized Reservations Systems Requires a Conscious Balance Between Consumer Protection and Profitable Airline Marketing", University of Denver Transportation Law Journal, 469 (1993), pp. 469518.

Lim, Aik Hoe and Bart De Meester, eds., WTO Domestic Regulation and Services Trade: Putting Principles into Practice (Geneva: WTO, 2014).

Lund, Susan, Toos Daruvala, Richard Dobbs, Philipp Häerle, Ju-Hon Kwek, and Falcón Ricardo, Financial Globalization: Retreat or Reset? (New York: McKinsey \& Company, McKinsey Global Institute, 2013).

Milde, Michael, International Air Law and ICAO (The Hague: Eleven International Publishing, 2008).

OECD, "Implementing the Latest International Standards for Compiling Foreign Direct Investment Statistics: FDI Statistics by the Ultimate Investing Country", 2015, available at http://www.oecd.org/daf/inv/FDI-statistics-by-ultimate-investingcountry.pdf.

Ostry, Sylvia, "The Domestic Domain: The New International Policy Arena", Transnational Corporations, 1 (February 1992), pp. 7-26.

Rathbone, Meredith, Peter Jeydel and Amy Lentz, "Sanctions, Sanctions Everywhere: Forging a Path Through Complex Transnational Laws", Georgetown Journal of International Law, 44 (2013), pp. 1055-1126.

Ravich, Timothy M., "Deregulation of the Airline Computer Reservation Systems (CRS) Industry", Journal of Air Law and Commerce, 69 (2004), pp. 387-412.

Ruffing, Lorraine, "Transparency and Disclosure: Lifting the Veil from Corporate Reporting", in Hamdani, Khalil and Lorraine Ruffing, United Nations Centre on Transnational Corporations: Corporate Conduct and the Public Interest (London: Routledge, 2015).

Sauvant, Karl P., "The Negotiations of the United Nations Code of Conduct on Transnational Corporations: Experience and Lessons Learned", Journal of World Investment and Trade, 16 (2015), pp. 11-87.

Stewart, Karen and Joseph Matthews, "Online Arbitration of Cross-Border, Business to Consumer Disputes”, University of Miami Law Review, 56 (2002), pp. 1111-1146.

Squire Sanders, Spotlight on Global Merger Control, 2012, available at http://www.squiresanders.com/files/Publication/24845123-1e98-4f89-892a.f842dca3f85f/Presentation/PublicationAttachment/b34e1ca8-8488-4475-96b9f99c9945e123/spotlight-on-global-merger-control.pdf.

UNCTAD, The Set of Multilaterally Agreed Equitable Principles and Rules for the Control of Restrictive Business Practices (adopted through United Nations General Assembly resolution 35/63 on December 5, 1980). 
UNCTAD, World Investment Report 2015: Reforming International Investment Governance (Geneva: United Nations, 2015).

UNCTAD, World Investment Report 2014. Investing in the SDGs: An Action Plan (Geneva: United Nations, 2014).

UNCTAD, World Investment Report 2013: Global Value Chains. Investment and Trade for Development (Geneva: United Nations, 2013).

UNCTAD, World Investment Report 2012: Towards a New Generation of Investment Policies (Geneva: UNCTAD, 2012).

UNCTAD, World Investment Report 2007: Transnational Corporations, Extractive Industries and Development (Geneva: UNCTAD: 2007).

UNCTAD, World Investment Report 2005: Transnational Corporations and the Internationalization of $R \& D$ (Geneva UNCTAD, 2005).

UNCTAD, World Investment Report 2002: Transnational Corporations and Export Competitiveness (Geneva: United Nations, 2002).

UNCTAD, World Investment Report 2000: Cross-border Mergers and Acquisitions and Development (Geneva: UNCTAD, 2000).

UNCTAD, World Investment Report 1999: Foreign Direct Investment and the Challenge of Development (Geneva: United Nations, 1999.

UNCTAD, World Investment Report 1995: Transnational Corporations and Competitiveness (Geneva: United Nations, 1995.

UNCTAD, World Investment Report 1993: Transnational Corporations and Integrated International Production (Geneva: United Nations, 1993).

UNCTAD-ICTSD, Resource Book on TRIPS and Development (Cambridge: Cambridge University Press, 2005).

United Nations, Multinational Corporations in World Development (New York: United Nations, 1973).

United States Government Accountability Office, "Bankruptcies: Complex Financial Institutions and International Coordination Pose Challenges", Report to Congressional Committees (Washington: U.S. G.A.O., July 2011), pp. 53-56.

Wilkins, Mira, The Emergence of Multinational Enterprise: American Business Abroad from the Colonial Era to 1914 (Cambridge, Mass.: Harvard University Press, 1970).

World Trade Organization, "Decision on Domestic Regulation", adopted by the Council for Trade in Services on 26 April 1999, document S/L/70 of April 28, 1999. 
World Trade Organization, "Disciplines on Domestic Regulation in the Accountancy Sector", adopted by the Council for Trade in Services on December 14, 1998, document S/L/64.

World Trade Organization, World Trade Report 2007 (Geneva: WTO, 2007).

World Trade Organization, "Report of the Working Party on the Accession of Yemen to the World Trade Organization. Schedule of Specific Commitments on Services List of Article II Exemptions. Addendum", WT/ACC/YEMEN/42/Add.2 of October 4, 2013.

Zagaris, Bruce, "BNP Paribas Pleads Guilty and Will Pay $\$ 8.9$ Billion for Economic Sanctions Violations", International Enforcement Law Reporter, 30 (October, 2014), pp. 381-384. 